\title{
Host suitability of soybean and corn genotypes to the root lesion caused by nematode under natural infestation conditions
}

\author{
Hospedabilidade de genótipos de soja e de milho ao nematoide \\ das lesões radiculares, sob condições naturais de infestação
}

\author{
Anderli Divina Ferreira Rios ${ }^{I}$ Mara Rúbia da Rocha ${ }^{\text {II }}$ Alan Soares MachadoIII \\ Kássia Aparecida Garcia Barbosa Ávila ${ }^{\text {IV }}$ Renato Andrade Teixeira ${ }^{I I}$ \\ Leonardo de Castro Santos ${ }^{V}$ Lilian Rosana Silva Rabelo ${ }^{\mathrm{VI}}$
}

ABSTRACT

Among the nematode management strategies, genetic resistance is one of the most appropriate and desirable. However, resistant soybean and corn genotypes resistant to Pratylenchus brachyurus are not available up to the moment. The objective of this study was to evaluate the host suitability of 50 soybean and 38 corn genotypes to $\boldsymbol{P}$. brachyurus under natural infestation. Soybean genotypes BRSGO Chapadões, BRSGO Paraíso, M-Soy 7211 RR, M-Soy 8008 RR, Emgopa 313 RR, M-Soy 8411, BRSGO Juliana RR, Emgopa 316 RR, BRSGO Luziânia RR and TMG 103 $R R$, and corn genotype Agromem $30 A 06$ reduced the nematode population during the evaluation period.

Key words: Glycine max, Zea mays, Pratylenchus brachyurus, resistance.

\section{RESUMO}

Dentre as estratégias de manejo de nematoides, a utilização de resistência é uma das alternativas mais apropriadas e desejáveis. No entanto, até o momento, não se dispõe de genótipos de soja e de milho reconhecidamente resistentes a Pratylenchus brachyurus. $O$ objetivo deste trabalho foi avaliar a reação de 50 genótipos de soja e 38 de milho a $\boldsymbol{P}$. brachyurus em áreas naturalmente infestadas. Os genótipos de soja BRSGO Chapadões, BRSGO Paraíso, M-Soy 7211 RR, M-Soy 8008 RR, Emgopa 313 RR, M-Soy 8411, BRSGO Juliana RR, Emgopa 316 RR, BRSGO Luziânia RR e TMG 103 RR e o de milho Agromem 30 A06 reduziram a população do nematoide ao longo do periodo de avaliação.

Palavras-chave: Glycine max, Zea mays, Pratylenchus brachyurus, resistência.
Pratylenchus brachyurus is widespread in Brazil and there are reports of its occurrence in many crops (MACHADO et al., 2006; ALVES et al., 2011; INOMOTO, 2011). In soybean, its importance has increased in recent years, especially in the Midwest region, in areas of maize second crop after soybean in no tillage production systems under irrigation and in sandy soils (GOULART, 2008). Corn is highly susceptible to nematodes, especially $\boldsymbol{P}$. brachyurus (LORDELLO et al., 1985; INOMOTO, 2011).

Among the main measures to control nematodes, the use of genetic resistance stands out. Although some preliminary research results regarding the reaction of soybean and corn genotypes to this nematode exist, data are not conclusive (ALVES et al., 2011; INOMOTO, 2011). Studies have been conducted under greenhouse and in field conditions in different locations in Brazil; however, few advances have been achieved, and, in some cases, with contradictory results. This can be attributed to different methods of evaluation and to the variability of the nematode present in different regions. For MACHADO et al. (2006) variability occurs in nematode populations leading to differences in the aggressiveness of $\boldsymbol{P}$. brachyurus. The fact that the interaction of $\boldsymbol{P}$. brachyurus with plants does not

\footnotetext{
IFaculdade Evangélica de Goianésia (FACEG), Av. Brasil, 1000, Bairro Covoá, 76380-000, Goianésia, GO, Brasil. E-mail: anderlidf@hotmail.com. Corresponding author.

"Laboratório de Nematologia, Escola de Agronomia (EA), Universidade Federal de Goiás (UFG), Goiânia, GO, Brasil.

III Instituto Federal Goiano, Campus Ceres, Ceres, GO, Brasil.

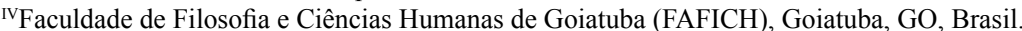

vInstituto Federal Goiano, Campus Iporá, Iporá, GO, Brasil.

${ }^{\mathrm{VI} I n s t i t u t o}$ Federal Roraima, Campus Amajari, Amajari, RR, Brasil. 
induce specialized feeding cell formation makes it difficult to find resistance and to elucidate the mechanisms involved (GOULART, 2008).

In order to evaluate commercial soybean and corn genotypes looking for resistance to $\boldsymbol{P}$. brachyurus two trials were carried out: one with soybeans in Vicentinópolis/GO and the other with corn in Edéia/GO. Both experiments were installed in commercial crops under conventional sowing systems naturally infested by the nematode, with a history of high nematode populations and the occurrence of stunted spots in the previous harvest. The experimental design was a randomized complete block with split plot over time, with 50 treatments (genotypes) and eight replications for soybean and 38 treatments (genotypes) and ten replications for corn. The evaluations were performed at 30 and 60 days after emergence (DAE). Each plot consisted of a $50 \mathrm{~cm}$ row, allowing a ten seed condensed sowing. Each row contained all genotypes ordered at random, composing a block.

For each evaluation, samplings were drawn collecting three plants from each plot. The shoots were discarded and the root systems taken to the laboratory for nematode extraction according to methodology described by COOLEN \& D'HERD (1972). Nematode density data were subjected to tests for normality and homogeneity of variance. Once the statistic assumptions were complied, the analysis of variance was performed with the ScottKnott test at the 5\% level of significance. Statistical tests were performed with data transformed into $y^{\prime}=$ $\mathrm{y}^{0.20}$ for soybean and $\mathrm{y}^{\prime}=\mathrm{y}^{0.057}$ for corn, according to BOX-COX (1964) and subjected to the analysis of variance, using SAS statistical software (1999).

The mean test $(\mathrm{P} \leq 0.05)$ separated the soybean genotypes into two groups in both evaluations (Table 1). The analysis showed interaction between genotypes and evaluation periods $(\mathrm{P} \leq 0.05)$ for 12 soybean genotypes; ten with population reduction (BRSGO Chapadões, BRSGO Paraiso, M-Soy 7211 RR, M-Soy 8008 RR, Emgopa 313 RR, M-Soy 8411, BRSGO Juliana RR, Emgopa 316, BRSGO Luziania RR and TMG 103 RR), ranging from $46 \%$ to $70 \%$. A possible explanation for the decline observed in the nematode population in the second evaluation is that the tested soybean cultivars have determined growth habit that paralyzes their growth after flowering, before entering the reproductive stage (NOGUEIRA et al., 2009). As roots stop growing, there is greater competition for food among nematodes, forcing their output from the plant or reducing their multiplication.
Other authors also tested some soybean genotypes tested in this study and, in some cases, results were confirmed. ALVES et al. (2011) also observed that cultivars 'Emgopa 313 RR' and 'M-Soy 8411', considered potentially resistant in this study, had low reproduction factor (RF) under controlled conditions. RIBEIRO et al. (2007) and MACHADO (2009) also found similar results for cultivar BRSGO Chapadões under greenhouse conditions. Conversely, 'TMG 103 RR' and 'BRSGO Paraiso' cultivars, which in the present study were considered resistant, presented high RF in a study by RIBEIRO et al. (2007).

The corm genotypes tested were divided by the mean test $(\mathrm{P} \leq 0.05)$ in three groups, in both evaluations (30 DAE and 60 DAE) (Table 2). From the corn genotypes tested, 16 significantly increased the nematode population density at $60 \mathrm{DAE}$, most with an increase of over $100 \%$. Similar results were found by LORDELLO et al. (1985), who also observed a gradual increase of nematodes $\boldsymbol{P}$. brachyurus and $\boldsymbol{P}$. zeae during the testing period in a trial in field with evaluations at 39, 59 and 90 DAS. INOMOTO (2011) studied the reaction of corn hybrids to $\boldsymbol{P}$. brachyurus under controlled conditions and observed RF ranging from 4.0 to 15.4 .

In this study, only four corn genotypes showed low population density in both evaluations, which can indicate genetic resistance (Table 2). They were P 30F80, GNZ 2500, DKB 350 and NK Impacto. Hybrid Agromem 30A06, despite being among those that showed high population densities in the first evaluation, was the one that had the density reduced by $58 \%$ at 60 DAE.

Diverse results reported in different studies for soybean and corn genotypes may be due to differences in the methods used for conducting and evaluating experiments. Extraction and counting of nematodes from roots may still be the most appropriate method to check nematode population density as well as to evaluate crop yield related to the existence of tolerance to $\boldsymbol{P}$. brachyurus under naturally infested field conditions. It is possible that the genotypes that remained with low nematode population density along the evaluation period may present mechanisms to make difficult the nematode penetration. Conversely, genotypes that presented significant reduction on the nematode population at the second evaluation may have some mechanism that works after the nematode has entered the roots. This suggests that new studies should look for mechanical or biochemical modifications in the plants due to the nematode parasitism.

Another hypothesis to explain the diversity of results when compared to other studies, is that 
Table 1 - Population density of $\boldsymbol{P}$. brachyurus (n. of individuals $10 \mathrm{~g}^{-1}$ of roots) at 30 and 60 days after emergence (DAE) in soybean genotypes. Vicentinópolis, GO. UFG, 2009.

\begin{tabular}{|c|c|c|c|c|c|}
\hline \multirow{3}{*}{$\begin{array}{l}\mathrm{N} \\
1\end{array}$} & \multirow{2}{*}{ GENOTYPES } & \multicolumn{4}{|c|}{ 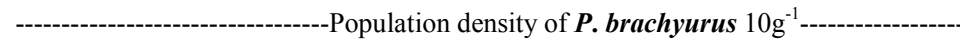 } \\
\hline & & \multicolumn{2}{|c|}{ 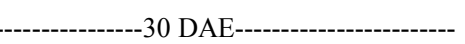 } & \multirow{2}{*}{2,176} & \multirow[b]{2}{*}{$a^{*}$} \\
\hline & NK 7074 RR & 1,182 & $\mathrm{a}$ & & \\
\hline 2 & BRSGO Araçu RR & 1,166 & $\mathrm{a}$ & 2,160 & $\mathrm{a}$ \\
\hline 3 & BRSGO 7963 & 507 & $\mathrm{~b}$ & 1,849 & $a^{*}$ \\
\hline 4 & M-SOY 7578 & 1,548 & $\mathrm{a}$ & 1,816 & a \\
\hline 5 & BRSGO Mineiros RR & 1,366 & $\mathrm{a}$ & 1,715 & $\mathrm{a}$ \\
\hline 6 & Emgopa 316 & 867 & $\mathrm{~b}$ & 1,605 & a \\
\hline 7 & BRS 7860 & 1,263 & $\mathrm{a}$ & 1,600 & a \\
\hline 8 & BRS Valiosa RR & 1,024 & $\mathrm{~b}$ & 1,511 & a \\
\hline 9 & Emgopa 302 RR & 1,670 & $\mathrm{a}$ & 1,473 & $\mathrm{a}$ \\
\hline 10 & M-SOY 8757 & 2,020 & $\mathrm{a}$ & 1,453 & $\mathrm{a}$ \\
\hline 11 & M-SOY 6101 & 1,020 & $\mathrm{~b}$ & 1,420 & a \\
\hline 12 & P 98R31 & 752 & $\mathrm{~b}$ & 1,400 & a \\
\hline 13 & MG/BR46 Conquista & 1,122 & $\mathrm{a}$ & 1,396 & a \\
\hline 14 & BRSGO Amaralina & 903 & $\mathrm{~b}$ & 1,366 & $\mathrm{a}$ \\
\hline 15 & BRSGO Caiapônia & 931 & $\mathrm{a}$ & 1,348 & a \\
\hline 16 & BRSGO 7760 RR & 1,883 & $\mathrm{a}$ & 1,331 & $\mathrm{a}$ \\
\hline 17 & BRSGO 8060 & 1,192 & $\mathrm{a}$ & 1,296 & $\mathrm{a}$ \\
\hline 18 & BRS $8160 \mathrm{RR}$ & 1,395 & $\mathrm{a}$ & 1,224 & $\mathrm{a}$ \\
\hline 19 & BRSGO Ipameri & 1,161 & $\mathrm{a}$ & 1,208 & a \\
\hline 20 & P 98Y11 & 1,623 & $\mathrm{a}$ & 1,175 & a \\
\hline 21 & BRS Favorita RR & 1,348 & $\mathrm{a}$ & 1,168 & $\mathrm{a}$ \\
\hline 22 & BRSGO Chapadões & 2,040 & $\mathrm{a}$ & 1,105 & $b^{*}$ \\
\hline 23 & BRS 8460 RR & 1,108 & $\mathrm{a}$ & 1,047 & $\mathrm{~b}$ \\
\hline 24 & TMG 115 RR & 636 & $\mathrm{~b}$ & 989 & $\mathrm{~b}$ \\
\hline 25 & M-SOY 8001 & 1,185 & $\mathrm{a}$ & 962 & $\mathrm{~b}$ \\
\hline 26 & BRS Iara & 1,272 & $\mathrm{a}$ & 959 & $\mathrm{~b}$ \\
\hline 27 & BRSGO Paraíso & 1,855 & $\mathrm{a}$ & 949 & $b^{*}$ \\
\hline 28 & BRS 8360 & 1,484 & $\mathrm{a}$ & 891 & $\mathrm{~b}$ \\
\hline 29 & BRSGO Luziânia & 1,475 & $\mathrm{a}$ & 886 & $\mathrm{~b}$ \\
\hline 30 & M-SOY 7211 RR & 2,254 & $\mathrm{a}$ & 879 & $b^{*}$ \\
\hline 31 & BRSGO 8560 RR & 1,275 & $\mathrm{a}$ & 873 & $\mathrm{~b}$ \\
\hline 32 & BRSGO Raíssa & 1,424 & $\mathrm{a}$ & 845 & $\mathrm{~b}$ \\
\hline 33 & M-SOY 8008 RR & 1,653 & $\mathrm{a}$ & 834 & $b^{*}$ \\
\hline 34 & Emgopa 314 & 718 & $\mathrm{~b}$ & 814 & $\mathrm{~b}$ \\
\hline 35 & M-SOY 9144 RR & 824 & $\mathrm{~b}$ & 795 & b \\
\hline 36 & BRSGO Indiara & 745 & $\mathrm{~b}$ & 760 & $\mathrm{~b}$ \\
\hline 37 & M-SOY 8200 & 992 & $\mathrm{~b}$ & 756 & $b$ \\
\hline 38 & CD 219 RR & 1,229 & $\mathrm{a}$ & 750 & $\mathrm{~b}$ \\
\hline 39 & Emgopa 315 RR & 1,079 & $\mathrm{a}$ & 749 & $\mathrm{~b}$ \\
\hline 40 & BRSGO Jataí & 838 & $\mathrm{~b}$ & 710 & b \\
\hline 41 & BRSGO Silvânia RR & 661 & $\mathrm{~b}$ & 704 & $\mathrm{~b}$ \\
\hline 42 & BRSGO Gisele RR & 863 & $\mathrm{~b}$ & 644 & b \\
\hline 43 & Emgopa 313 RR & 1,225 & $\mathrm{a}$ & 622 & $b^{*}$ \\
\hline 44 & M-SOY 7908 RR & 838 & $\mathrm{~b}$ & 615 & $\mathrm{~b}$ \\
\hline 45 & Emgopa 313 & 734 & $\mathrm{~b}$ & 578 & $\mathrm{~b}$ \\
\hline 46 & M-SOY 8411 & 1,259 & $\mathrm{a}$ & 526 & $b^{*}$ \\
\hline 47 & BRS Juliana RR & 1,364 & $\mathrm{a}$ & 513 & $b^{*}$ \\
\hline 48 & Emgopa 316 RR & 1,089 & $\mathrm{a}$ & 468 & $b^{*}$ \\
\hline 49 & BRS Luziânia RR & 1,475 & $\mathrm{a}$ & 434 & $b^{*}$ \\
\hline 50 & TMG 103 RR & 810 & $\mathrm{~b}$ & 340 & $b^{*}$ \\
\hline $\mathrm{CV}$ & & & & & \\
\hline
\end{tabular}

Means followed by the same letter in the column do not differ by the Scott-Knott test at the $5 \%$ level of significance. After the analysis of variance data were transformed into $\mathrm{y}^{\prime}=\mathrm{y}^{0.20}$.

${ }^{*}$ Significant interaction between evaluation periods.

there may be differences of aggressiveness among nematode populations of $\boldsymbol{P}$. brachyurus from different regions of Brazil (FALLAS et al., 1996; MACHADO et al., 2006), suggesting that studies to characterize the behavior of soybean and corn genotypes to this nematode should be sustained.

The genotypes of soybean and corn that remained with the lowest population densities in 
Table 2 - Population density of $\boldsymbol{P}$. brachyurus (n. of individuals $10 \mathrm{~g}^{-1}$ of roots) at 30 and 60 days after emergence (DAE) in corn genotypes. Edéia, GO. UFG, 2009.

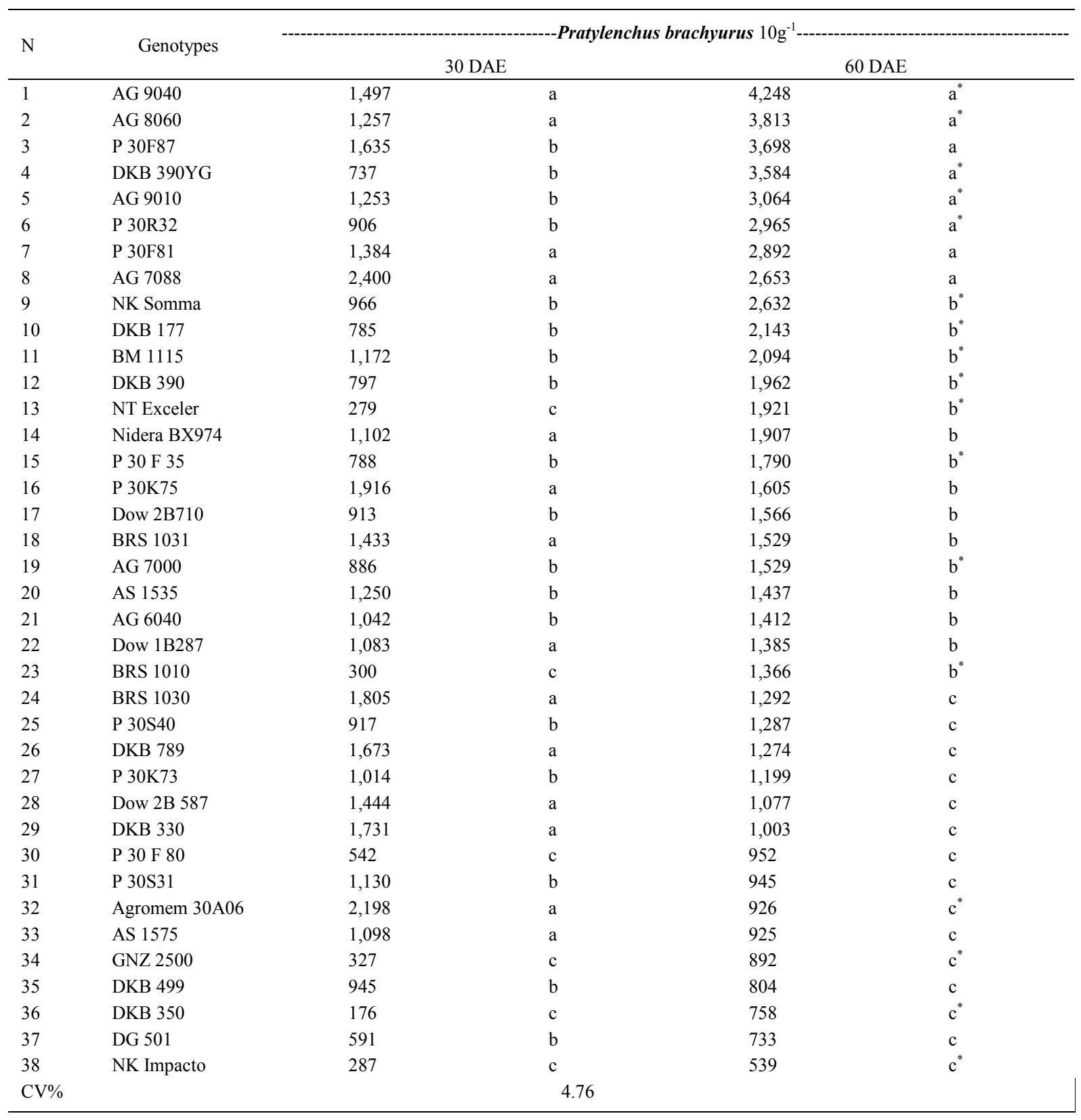

Means followed by the same letter do not differ by the Scott-Knott test at the $5 \%$ level of significance. For the analysis of variance data were transformed into $\mathrm{y}^{\prime}=\mathrm{y} 0.057$.

"Significant interaction between evaluation periods at $5 \%$.

the two evaluation periods or significantly reduced the population in the second evaluation can be considered moderately resistant and be good choices for sowing in areas infested by the nematode. They can also be targeted for further investigations identifying genetic resistance.

\section{REFERENCES}

ALVES, T.C.U. et al. Host status of soybean cultivars to lesion nematode Pratylenchus brachyurus. Revista Biodiversidade, v.10, n.1, p.73-79, 2011. Available from: <http:// periodicoscientificos.ufmt.br/index.php/biodiversidade/article/ view/538/459>. Accessed: Jan. 10, 2014. 
BOX, G.E.P.; COX, D.R. An analysis of transformations. Journal of the Royal Statistical Society. Series B (Statistical Methodological), v.26, n.2, p.211-252, 1964.

COOLEN, W.A.; D'HERDE, C.J. A method for the quantitative extraction of nematodes from plant tissue. State of Nematology and Entomology Research Station, 1972. 77p.

FALLAS, G.A. et al. Molecular and biochemical diversity among isolates of Radopholus spp. from different areas of the world. Jounal of Nematology, v.28, n.4, p.422-430, 1996. Available from: <http://journals.fcla.edu/jon/article/view/66835/64503>. Accessed: Jan. 5, 2015.

GOULART, A.M.C. Aspectos gerais sobre nematoides das lesões radiculares (gênero Pratylenchus). Embrapa Cerrados, 2008. 30p. (Documentos - ISSN 1517-5111; 219).

INOMOTO, M.M. Resistance evaluation of 12 maize hybrids to Pratylenchus brachyurus. Tropical Plant Pathology, v.36, n. 5, p.308-312, 2011. Available from: <http://www.scielo.br/pdf/ tpp/v36n5/v36n5a06.pdf>. Accessed: Jan. 18, 2015. doi: 10.1590/ S1982-56762011000500006

LORDELLO, R.A. et al. Reação de genótipos de milho a Pratylenchus spp. em campo. Nematologia Brasileira, v.9, n. 1, p.163-173, 1985 .
MACHADO, A.C.Z. et al. Evaluation of cotton damages caused by Pratylenchus brachyurus. Fitopatologia Brasileira, v.31, n.1, p.11-16, 2006. Available from: <http:// www.scielo.br/pdf/fb/v31n1/a02v31n1.pdf $>$. Accessed: Jan. 25, 2014. doi: 10.1590/S0100-41582006000100002

MACHADO, A.C.Z. Host status of some selected Brazilian soybean cultivars to Pratylenchus brachyurus. In: INTERNATIONAL CONGRESS OF TROPICAL NEMATOlOGY, 2., 2009, Maceió, Al. Resumos... Maceió: Brazilian Nematological Society (BNS) and Organization of Nematologists of Tropical America (ONTA). 2009. V. 1, p.76.

NOGUEIRA, A. P. O. et al. Morfologia, Crescimento e Desenvolvimento. In: SEDIYAMA, T. Tecnologias de produção e usos da soja. Londrina: Mecenas, 2009. 314p. cap.1, p.7 - 16 .

RIBEIRO, N.R. et al. Avaliação da reação de espécies vegetais ao nematoide das lesões radiculares. In: REUNIÃO DE PESQUISA DA SOJA DA REGIÃO CENTRAL DO BRASIL, 29., 2007, Campo Grande, MS. Resumos... Londrina: Embrapa Soja/ Uniderp, 2007, v.1, p.62-63.

STATISTICAL ANALYSIS SYSTEM - SAS. User's guide: statistic. 6.ed. Cary, 1999. 956p. 